\title{
Introduction of an alien fish species in the Pilbara region of Western Australia
}

\author{
Dean C. Thorburn', James J. Keleher ${ }^{1}$ and Simon G. Longbottom ${ }^{1}$ \\ ${ }^{1}$ Indo-Pacific Environmental, PO Box 191, Duncraig East, Western Australia 6023, Australia. \\ * Corresponding author: dthorburn@indopacific.net.au
}

\begin{abstract}
Until recently rivers of the Pilbara region of north Western Australia were considered to be free of introduced fish species. However, a survey of aquatic fauna of the Fortescue River conducted in March 2017 resulted in the capture of 19 Poecilia latipinna (Sailfin Molly) throughout a $25 \mathrm{~km}$ section of the upper catchment. This represented the first record of an alien fish species in the Pilbara region and the most northern record in Western Australia. Based on the size of the individuals captured, the distribution over which they were recorded and the fact that the largest female was mature, P. latipinna appeared to be breeding. While P. latipinna was unlikely to physically threaten native fish species in the upper reaches of the Fortescue River, potential spatial and dietary competition may exist if it reaches downstream waters where native fish diversity is higher and dietary overlap is likely. As P. latipinna has the potential to affect macroinvertebrate communities, some risk may also exist to the macroinvertebrate community of the Fortescue Marsh, which is located immediately downstream, and which is valued for its numerous short range endemic aquatic invertebrates. The current finding indicated that despite the relative isolation of the river and presence of a low human population, this remoteness does not mean the river is safe from the potential impact of species introductions. Indeed, the presence of $P$. latipinna in this system highlights the potential for future introductions in other remote rivers of northern Australia where transient human populations, or those which fluctuate greatly with economic circumstance, are present.
\end{abstract}

KEYWORDS: mining, environmental impact, freshwater, introduced species, invasive fish, Poecilia latipinna, Sailfin Molly, Australia.

\section{INTRODUCTION}

From an aquatic resource perspective, the Pilbara region of north Western Australia is considered to include that area encompassing the catchments of the Ashburton, Robe, Fortescue and De Grey Rivers (McFarlane and Hodgson 2015) (Figure 1). This area has also been referred to as the Northern Pilbara Subprovince by Morgan and Gill (2004), who based their definition on the fact that a distinct suite of fish existed in the rivers of the region. Twelve species of freshwater fish have been recorded from the Pilbara, which includes Leiopotherapon aheneus and an undescribed plotosid which are endemic to the region (Morgan and Gill 2004, Morgan et al. 2014a).

The Fortescue River (Figure 1) is an ephemeral river which arises in the Ophthalmia Range (near the town of Newman) and is the longest waterway in the Pilbara extending for $760 \mathrm{~km}$ (Department of Environment and Conservation 2009). For a number of years the aquatic fauna occurring in the middle and upper reaches of the Fortescue River have received particular attention due to the close proximity of several large iron ore mining operations. In addition, the presence of the Fortescue Marsh, which is listed as a 'Priority 1 Ecological Community' (PEC) by the Western Australian Government Department of Biodiversity, Conservation and Attractions and on the 'Directory of Important Wetlands in Australia' as a wetland of national significance (Australian Government Department of the Environment and Energy 2017b), has required additional management by mining companies operating in close proximity to negate potential impacts associated with water extraction and modification of surface water flows in the river.

In July 2016 and March 2017, a survey of aquatic fauna was undertaken over a $\sim 75 \mathrm{~km}$ section of the Fortescue River which included sample sites located both above and below Ophthalmia Dam (Figure 1). Published accounts of the riverine fish fauna of the Pilbara have been provided by Allen et al. (2002), Morgan and Gill (2004), Morgan et al. (2014a) and Morgan et al. (2014b). In addition, numerous technical reports (see for example Wetland Research and Management 2009, 2015a, 2015b, Taukulis 2016) have reported on the fish fauna present in and around the area surveyed during the current study, including Ophthalmia 


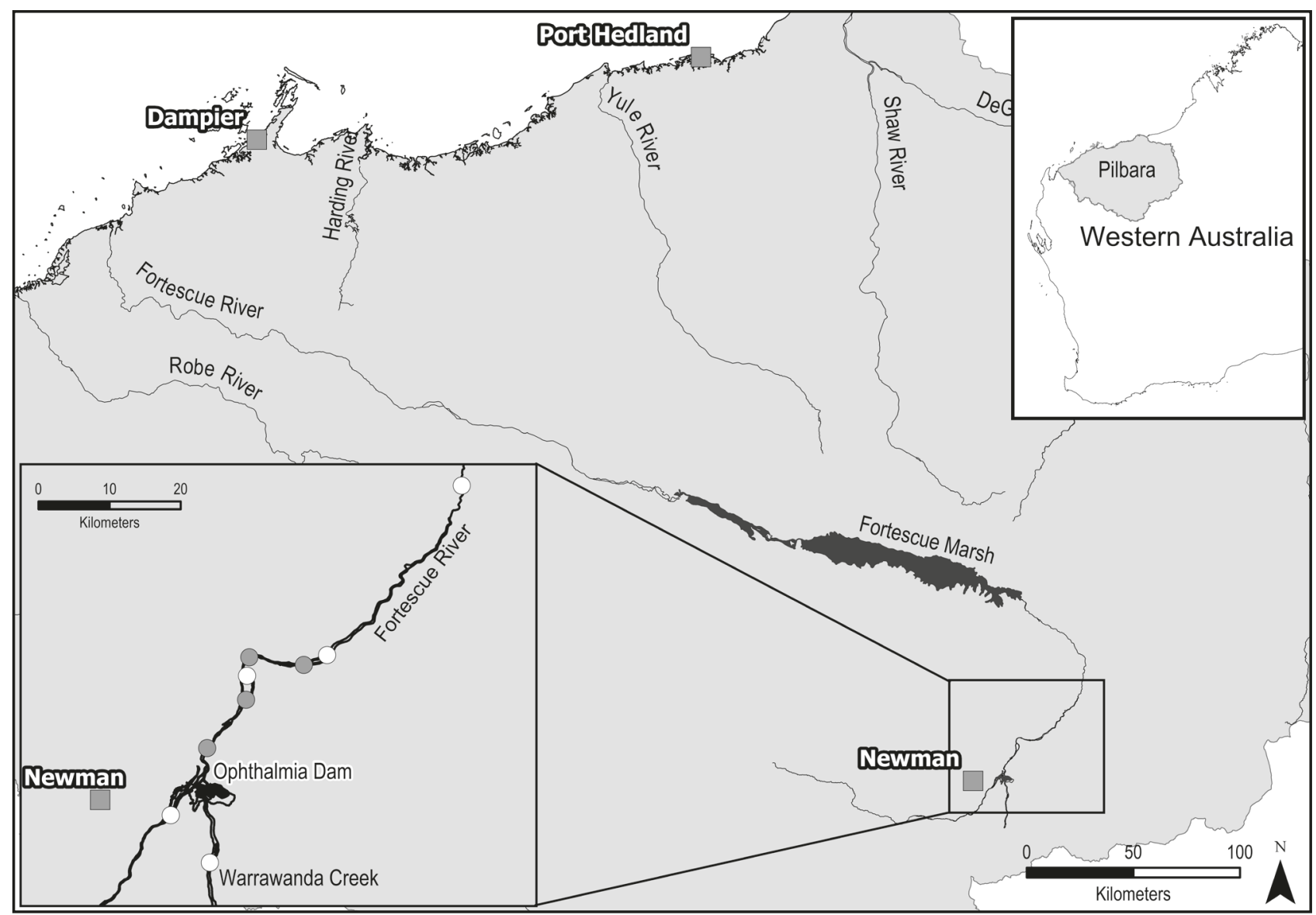

FIGURE 1 The Pilbara region of Western Australia and sites surveyed for fish in the Fortescue River. Grey shading in the inset indicates Poecilia latipinna capture locations.

Dam. Until the current survey, those studies have only accounted for three species of fish being present in the study area; Leiopotherapon unicolor (Spangled Perch), Melanotaenia australis (Western Rainbowfish) and Neosilurus hyrtlii (Hyrtl's Tandan). More importantly none of these authors have reported the presence of any introduced fish species in the Fortescue River or any other river of the Pilbara region.

Tedesco et al. (2013) predicted that freshwater fish extinction rates within river basins of the Pilbara will be amongst the highest on the planet due to water availability shrinkage associated with climate change. Furthermore, Morgan et al. (2014b) discussed that dewatering of habitats during mining and water abstraction are likely to result in impacts to fish and fish habitat in the region. Our paper discusses an additional threatening process, the introduction of alien species, and the potential ecological impact they may have on other fish species occurring in the Fortescue River. We discuss the introduction of an ornamental species, how it may have occurred, and highlight the potential for future introductions in other remote rivers of northern Australia where transient human populations, or those which fluctuate greatly with economic circumstance, are present.

\section{METHODS}

Sampling for fish was undertaken at three sites during July 2016 and nine sites in March 2017 (Figure 1). A range of sampling methods were utilised including fyke nets (set overnight with one facing upstream and one downstream), seine netting and electrofishing. Sampling was conducted at two sites in the Fortescue River main channel and one site in the tributary, Jimblebar Creek, in July 2016. Six sites were surveyed in the main channel of the Fortescue River in March 2017 with five of these located downstream of Ophthalmia Dam. An additional site upstream of Ophthalmia Dam was also surveyed on Warrawanda Creek in March 2017, as well as two sites on Jimblebar Creek. Native fish were identified to species and a total length measurement taken prior to their live release. Introduced fish were euthanised in accordance with survey conditions outlined by the Western Australian Government Department of Fisheries and several individuals were retained for lodgement with the Western Australian Museum.

During the July survey period, the Fortescue River was found to be flowing due to water being released from Ophthalmia Dam. As such, sampling occurred as far downstream as the Jigalong Road crossing which is located $\sim 64 \mathrm{~km}$ downstream of the Ophthalmia Dam levee wall. The Fortescue River was also found 
to be flowing during March 2017 due to recent heavy rainfall. Water was subsequently being released from Ophthalmia Dam in order to manage high water levels. The tributaries, Jimblebar and Warrawanda Creek, were also found to be flowing. The river bed was dry at the Jigalong Road crossing in March 2017 despite these recent rains. Sampling was subsequently conducted as far as $\sim 32 \mathrm{~km}$ downstream from the Ophthalmia Dam levee wall at that time. Inspection of another site $\sim 49 \mathrm{~km}$ downstream of the Ophthalmia Dam levee wall was also found to be dry.

\section{RESULTS}

No Poecilia latipinna were captured during the July 2016 sampling event. In contrast, 19 P. latipinna were captured at four sites surveyed during March 2017 over a $\sim 25 \mathrm{~km}$ section of river located downstream of Ophthalmia Dam (Figures 1-2). Twelve individuals were captured in fyke nets and all were found to be moving in a downstream direction. Seven P. latipinna were captured whilst electrofishing. Four individual $P$. latipinna were submitted to the Western Australian Museum (WAM P.34821-001).
The conductivity of water in which Poecilia latipinna was captured ranged from 0.007 to $0.235 \mathrm{mS} / \mathrm{cm}$ whilst salinity ranged from 0.0 to $0.1 \mathrm{ppt}$. Dissolved oxygen ranged from 4.39 to $6.62 \mathrm{mg} / \mathrm{L}$, water temperature from 28.2 to $32.4^{\circ} \mathrm{C}$ and $\mathrm{pH}$ from 7.39 to 8.90 . Three individuals were male based on the presence of a gonopodium and ranged in total length (TL) from 51 to $56 \mathrm{~mm}$. Fifteen were female and ranged in length from 40 to $61 \mathrm{~mm}$ TL (Figure 3). Eggs were released when pressure was applied to the largest female and inspection of the gonad revealed enlarged ovaries indicating maturity.

\section{DISCUSSION}

During the current study, the alien Poecilia latipinna (Sailfin Molly) was captured from the Fortescue River. This represents the first record of an introduced fish species from a river in the Pilbara region, and at the time of writing was the most northern catchment from which an alien fish species had been recorded in Western Australia (Morgan et al. 2014a, 2014b).

Despite the popularity of Poecilia latipinna as an ornamental aquarium species in Australia, few records of the species release or presence in Australian rivers

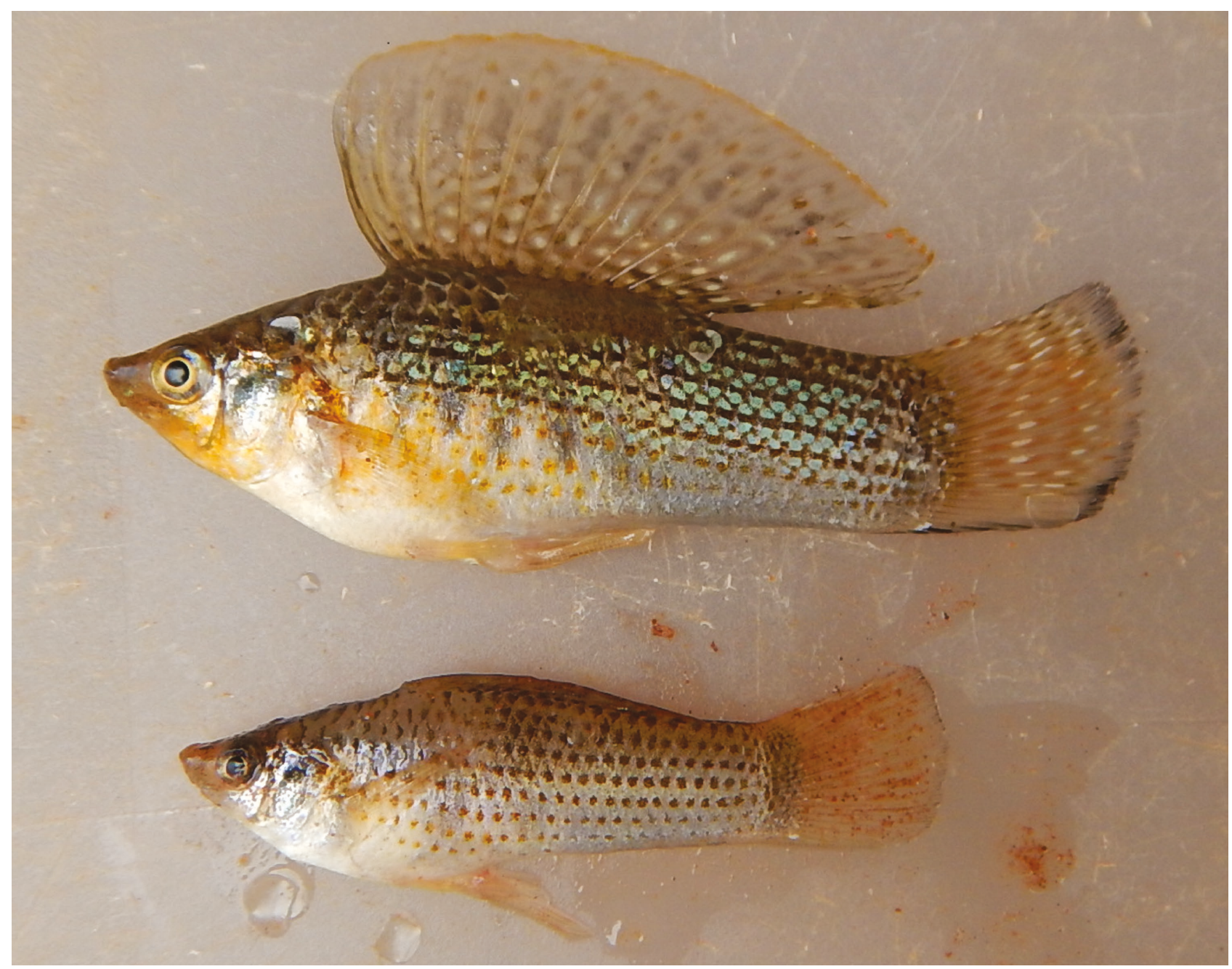




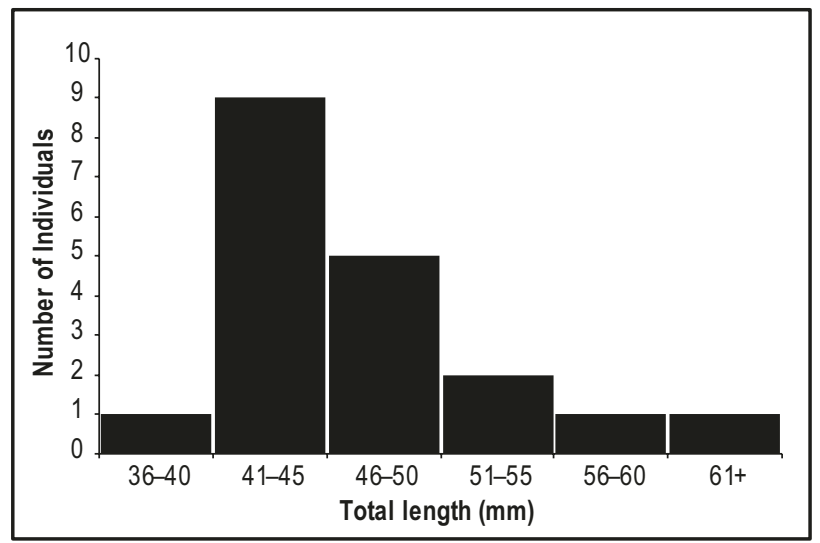

FIGURE 3 Length-frequency histogram of Poecilia latipinna captured from the Fortescue River, Western Australia, in March 2017.

appear to exist. The reviews of Lintermans (2004) and Corfield et al. (2008) cited P. latipinna as being present at several sites in Queensland and in waters near Darwin in the Northern Territory, though not in Western Australia. The Atlas of Living Australia (2018) also indicated specimens are held in the South Australian Museum Ichthyology Collection, with no location data for the collection site provided. Furthermore, there are no records of $P$. latipinna occurring in the Pilbara, or any other Western Australian river, on the PestWatch database maintained by the Department of Primary Industries and Regional Development (2017).

While the exact timing of the introduction of Poecilia latipinna in the Fortescue River is unknown, it was considered likely to have occurred in the months prior to the March 2017 sampling event. This was due to the fact that no P. latipinna were captured during the July 2016 sampling event or during other recent surveys in the area including that of Ophthalmia Dam (Taukulis 2016). This species has been considered to be a poor swimmer that prefers slow flowing waters (see Corfield et al. 2008). In light of this, and the fact that all individuals captured by fyke net were seen to be moving in a downstream direction, the distribution of $P$. latipinna from the release point was likely to have occurred in a downstream direction. Despite the species poor swimming ability, the fact that $P$. latipinna was found to have spread throughout 25 kilometres of the river in a short period of time (i.e. several months), suggests that colonisation of the Fortescue River by this species may be rapid particularly if flow is present.

It is unclear at this point whether Poecilia latipinna is likely to establish a permanent population in the upper Fortescue River. However, the species is likely to persist as it is known to have a broad salinity tolerance (tolerating freshwater up to hypersaline 80 ppt, Nordlie et al. 1992) and its invasiveness was rated by Arthington et al. (1999) as being very high. Growth and maturation rates of $P$. latipinna are known to be highly variable though water temperature and salinity are known to be key components. For example, the study by Trexler et al. (1990) reported that female P. latipinna grew over $250 \%$ faster in waters of $29^{\circ} \mathrm{C}$ than in waters of $23^{\circ} \mathrm{C}$. Water temperatures at the time of the survey ranged from 28.2 to $32.4^{\circ} \mathrm{C}$ which would appear favourable for growth. Trexler et al. (1990) also found male $P$. latipinna grew thirty percent faster at 20 ppt salinity than at 2 ppt whilst females grew fifty percent faster at $20 \mathrm{ppt}$ than at $2 \mathrm{ppt}$. Furthermore, higher salinities are generally maintained in captive breeding programs of $P$. latipinna with a salinity of $25 \mathrm{ppt}$ yielding both faster growth rates and the most fry per clutch (Kumaraguru Vasagam et al. 2005). Considering water in the upper Fortescue River at the time of the current study was essentially fresh, this may be less favourable for growth. Despite variation in environmental conditions, elsewhere in the world $P$. latipinna has been found to be reproductively active throughout the year (Al-Akel et al. 2010) with multiple spawning events occurring (Corfield et al. 2008) and females producing up to 100 fry every 8-10 weeks (Yamamoto and Tagawa 2000). In relation to size at maturity, a study from Saudi Arabia found males were mature at $51 \mathrm{~mm}$ TL while female maturity was attained at $48 \mathrm{~mm}$ TL (Al-Akel et al. 2010). However, Trexler et al. (1990) found P. latipinna to mature when smaller, with females maturing at a standard length of approximately $28 \mathrm{~mm}$ and males at approximately $25 \mathrm{~mm}$ in freshwater environments. Although the salinity in the upper Fortescue River was found to be well below optimal growth and breeding salinities during the current survey, based on the range in total fish lengths recorded, the geographical distance over which individuals were captured, and the presence of a mature egg-bearing female, it was considered likely that $P$. latipinna had bred in the Fortescue River and that captured individuals were not the result of a single release.

Elsewhere in the world Poecilia latipinna has been known to have contributed to the decline of fish species and affected macroinvertebrate communities (Corfield et al. 2008). However, it is unclear whether this would occur in the upper reaches of the Fortescue River. Dietary studies by Alkahem et al. (2007) and the report by Corfield et al. (2008) indicated P. latipinna to be herbivorous and consuming mainly algae. Therefore, little dietary competition is likely to exist with the native fish species present based on the fact that, in addition to algae, Leiopotherapon unicolor consumes a large proportion of aquatic invertebrates and fish, and Melanotaenia australis consumes a large proportion of aquatic invertebrates (Bishop et al. 2001, Thorburn et al. 2014). Furthermore, in a dietary study conducted in a Kimberley river, Neosilurus hyrtlii was found to 
consume mainly ostracods (Thorburn et al. 2014) while Allen et al. (2002) describe a diet of insects, molluscs, crustaceans and worms. Corfield et al. (2008) also indicated that $P$. latipinna was not aggressive in contrast to L. unicolor (Kennard 1995, Government of Western Australia Department of Fisheries 2012). Therefore, it is unlikely that $P$. latipinna would compete spatially with L. unicolor. The abundance and wide distribution of L. unicolor, M. australis and N. hyrtlii (Allen et al. 2002) also means that $P$. latipinna is unlikely to threaten broader populations of these species in the region.

Despite the fact $P$. latipinna is unlikely to out compete native fish species of the upper Fortescue River in terms of prey and space, its presence represents a reduction in the 'natural value' of the river. It is also unclear what broader ecological implications $P$. latipinna will have should the species be able to spread to downstream sections of the river. Native fish diversity is greatly increased in the lower reaches of the river (Morgan and Gill 2004) and as such an increased likelihood of dietary and spatial competition with native species exists. Immediately downstream of the survey area is the Fortescue Marsh which is afforded protection under both Western Australian State and Australian Federal legislation. While the Fortescue Marsh is highly ephemeral inundating every five to seven years (Department of Environment and Conservation 2009), connection with the lower Fortescue River can occur during extreme rainfall events (Fortescue Metals Group 2006). While the ephemeral nature of the Fortescue Marsh may provide some hindrance to the downstream colonisation of $P$. latipinna, with successive flows it is possible that it may reach the marsh and subsequently the lower Fortescue River should a significant rainfall event occur, such as that associated with a cyclone. Based on the observed effect of $P$. latipinna on macroinvertebrate communities elsewhere in the world (Corfield et al. 2008), some risk may also exist to the macroinvertebrate community of the Fortescue Marsh which is valued for containing numerous short range endemic aquatic invertebrate species (Environmental Protection Authority 2013, Robertson 2014). In addition, the introduction of aquarium species of fish may provide a vector for the introduction of foreign diseases or parasites into Australian rivers and the native fish fauna present (Hassan et al. 2008, Lymbery et al. 2010).

The sites at which $P$. latipinna were captured during the current study were downstream of Ophthalmia Dam, a popular recreational site for people residing in the town of Newman located $16 \mathrm{~km}$ away. This area is well known for its extensive iron ore reserves with the township of Newman being established by the Mount Newman Mining Company in 1966 as a company town. Iron ore is the largest export commodity in Australia and $95 \%$ of this production occurs in the Pilbara (Regional Development Australia 2014). In recent years, the price of iron ore has rapidly declined (Port Jackson Partners 2015) with a price fall of over $40 \%$ occurring in 2015 alone (Government of Western Australia Department of State Development 2016). This decline or 'downturn' in the mining sector had major implications for the Pilbara with the region's labour market significantly declining. In particular, over 23,000 jobs have been lost from the Pilbara in recent years, representing a $27 \%$ decline in the regional workforce (Western Australian Local Government Association 2017). While much of the mining workforce in the Pilbara operates on a 'fly in, fly out' basis, regional towns located close to iron ore mining operations also reported a significant population decline. This included Newman, with more than 400 people leaving the town between June 2014 and 2015 (i.e. 7\% of the population, Australian Bureau of Statistics 2017). The decline in economic growth and thus population in Pilbara towns has continued since 2015 and is expected to continue in the short term (Western Australian Local Government Association 2017).

Poecilia latipinna cannot be purchased in Newman and the presence of the species in the river is thought to be due to the release of individuals previously kept in a private aquarium. Based on the continued decline in population in Newman due to a lack of employment, and difficulty in moving aquarium fish, it is possible that the release of $P$. latipinna is an indirect result of the mining sector downturn whereby the release was by an individual leaving the town.

Despite the relative isolation of rivers in the Pilbara region and the low human population, the current study indicated that the remoteness of a river does not mean it is safe from the potential impact of species introductions. The presence of $P$. latipinna in the Fortescue River highlights the potential for future introductions in rivers of the Pilbara region and other remote areas where transient human populations occur. While the ecological implications of the ornamental $P$. latipinna in the Fortescue River are not currently understood, it is important for resource managers to recognise the current risk to northern Western Australian rivers and other rivers throughout regional Australia, which to date largely remain free of feral fish species (Pusey et al. 2017). As well as an education campaign highlighting the risk of introducing fish to remote rivers, management actions could include a registry of ornamental fish suppliers in northern regions of Western Australia to provide an indication of the location, species and numbers of ornamental fish being traded. Furthermore, an action plan aimed at responding to new introductions and potentially eradicating introduced species during the early phase of colonisation in remote rivers is considered important for maintaining native biodiversity and the 'natural value' of these remote river systems. 


\section{ACKNOWLEDGEMENTS}

We thank two anonymous reviewers whose comments assisted with improvements to this manuscript.

\section{REFERENCES}

Al-Akel A.S., Al-Misned F., Al-Kahem-Al-Balawai H.F., Al-Ghanim K.A., Ahmad Z. and Annazri, H. (2010). Reproductive biology of sailfin molly, Poecilia latipinna (Lesueur, 1821) in Wadi Haneefah stream, Riyadh, Saudi Arabia. Pakistan Journal of Zoology 42: 169-176.

Allen G.R., Midgley S.H. and Allen M. (2002). Field Guide to the Freshwater Fishes of Australia. Western Australian Museum, Perth.

Alkahem H.F., Al-Ghanim A. and Ahmad Z. (2007). Studies on feeding ecology of sailfin molly (Poecilia latipinna) dwelling in Wadi Haneefah Stream, Riyadh. Pakistan Journal of Biological Sciences 10: 335-341.

Arthington A.H., Kailola P.J., Woodland D.J. and Zalucki J.M. (1999). Baseline Environmental Data Relevant to an Evaluation of Quarantine Risk Potentially Associated with the Importation to Australia of Ornamental Finfish. Australian Quarantine and Inspection Service, Department of Agriculture, Fisheries and Forestry, Canberra.

Atlas of Living Australia (2018). Poecilia latipinna (Lesueur, 1821). Available at http://bie.ala.org.au/species/ Poecilia+latipinna [Accessed 21 April 2018]

Australian Bureau of Statistics (2017). Newman. [online] Available at http://stat.abs.gov.au/itt/r.jsp?RegionSummary andregion $=508061221$ anddataset $=$ ABS_REGIONAL_AS GSandgeoconcept $=$ REGIONanddatasetASGS $=$ ABS REGIONAL ASGSanddatasetLGA=ABS_NRP9_LGAand regionLGA $=\overline{\mathrm{R}} \mathrm{EGIONandregion} \mathrm{ASGS}=\mathrm{REGION}[\overline{\text { Accessed }}$ 20 June 2017].

Australian Government Department of the Environment and Energy (2017b). Directory of Important Wetlands [online] Available at http://www.environment.gov.au/cgi-bin/ wetlands/report.pl?smode=DOIW;doiw_refcodelist=WA066 [Accessed 20 June 2017].

Bishop K.A., Allen S.A., Pollard D.A. and Cook M.G. (2001). Ecological Studies on the Freshwater Fishes of the Alligator Rivers Region, Northern Territory: Autecology. Supervising Scientists Report 145. Supervising Scientist, Darwin.

Corfield J., Diggles B., Jubb C., McDowall R.M., Moore A., Richards A. and Rowe D.K. (2008). Review of the Impacts of Introduced Ornamental Fish Species that have Established Wild Populations in Australia. Prepared for the Australian Government Department of the Environment, Water, Heritage and the Arts, Canberra.

Department of Environment and Conservation (2009). Resource Condition Report for Significant Western Australian Wetland: Wetlands of the Fortescue River System. Department of Environment and Conservation, Perth.

Department of Primary Industries and Regional Development (2017). WA PestWatch. [online] Available at http://www. fish.wa.gov.au/Sustainability-and-Environment/AquaticBiosecurity/Identifying-Pests-And-Diseases/Pages/WAPestWatch.aspx [Accessed 04 August 2017]

Environmental Protection Authority (2013). Environmental and Water Assessments Relating to Mining and Mining-related Activities in the Fortescue Marsh Management Area. Advice of the Environmental Protection Authority to the Minister for Environment under Section 16(e) of the Environmental
Protection Act 1986. Environmental Protection Authority, Perth.

Fortescue Metals Group (2006). Fortescue Marshes Management Plan. Fortescue Metals Group, Perth.

Government of Western Australia Department of Fisheries (2012). Aquatic Biosecurity Alert. Spangled Perch (Leiopotherapon unicolor). Department of Fisheries, Perth.

Government of Western Australia Department of State Development (2016). Western Australian Iron Ore Industry Profile. Department of State Development, Perth.

Hassan, M., Beatty, S.J., Morgan, D.L., Doupé, R.G. and Lymbery, A.J. (2008) An introduced parasite, Lernaea cyprinacea $\mathrm{L}$., found on native freshwater fishes in the south west of Western Australia. Journal of the Royal Society of Western Australia 91: 149-153.

Kennard M.J. (1995). Factors influencing freshwater fish assemblages in floodplain lagoons of the Normanby River, Cape York Peninsula: a large tropical Australian river. M. Phil. Thesis, Griffith University, Brisbane.

Kumaraguru Vasagam K.P., Rajagopal S. and Balasubramanian T. (2005). Effect of salinity on gestation period, fry production, and growth performance of the sailfin molly (Poecilia latipinna Lesueur) in captivity. Israeli Journal of Aquaculture 57: 147-152.

Lintermans M. (2004). Human assisted dispersal of alien freshwater fish in Australia. New Zealand Journal of Marine and Freshwater Research 38: 481-501.

Lymbery, A.J., Hassan, M., Morgan, D.L., Beatty, S.J. and Doupé, R.G. (2010). Parasites of native and exotic freshwater fishes in south-western Australia. Journal of Fish Biology 76: 1770-1785.

McFarlane, D. and Hodgson, G. (2015). Chapter 1: Introduction. In: McFarlane, D.J. (ed.) Pilbara Water Resource Assessment. A report to the Government of Western Australia and industry partners from the CSIRO Pilbara Water Resource Assessment. CSIRO Land and Water, Australia.

Morgan D.L., Allen M. G., Beatty S.J., Ebner B.C. and Keleher J.J. (2014a). A Field Guide to the Freshwater Fishes of Western Australia's Pilbara Province. Freshwater Fish Group, Murdoch University, Murdoch.

Morgan D.L. and Gill H.S. (2004). Fish fauna in inland waters of the Pilbara (Indian Ocean) Drainage Division of Western Australia - evidence for three subprovinces. Zootaxa 636: $1-43$.

Morgan D.L., Unmack P.J, Beatty S.J., Ebner B.C., Allen M.G., Keleher J.J., Donaldson J.A. and Murphy J. (2014b). An overview of the 'freshwater fishes' of Western Australia. Journal of the Royal Society of Western Australia 97: 263-278.

Nordlie F.G., Haney D.C. and Walsh, S.J. (1992). Comparisons of salinity tolerances and osmotic regulatory capabilities in populations of sailfin molly (Poecilia latipinna) from brackish and fresh waters. Copeia 1992: 741-746.

Port Jackson Partners (2015). Iron Ore: The Bigger Picture. Minerals Council of Australia, Canberra.

Pusey, B.J., Burrows, D.W., Kennard, M.J., Perna, C.N., Unmack, P.J., Allsop, Q. and Hammer, M.P. (2017). Freshwater fishes of northern Australia. Zootaxa 4253: $1-104$.

Regional Development Australia (2014). The Pilbara: Resources and Beyond. Department of Infrastructure and Regional Development, Canberra. 
Robertson H. (2014). A wetland oasis - Fortescue Marsh. Species and Communities Branch Newsletter 20: 1-2.

Taukulis F. (2016). Ophthalmia Dam Aquatic Fauna Survey. MWH, Perth.

Thorburn D.C, Gill H.S. and Morgan D.L. (2014). Predator and prey interactions of fishes of a tropical Western Australia river revealed by dietary and stable isotope analyses. Journal of the Royal Society of Western Australia 97: 363-387.

Trexler J., Travis J. and Trexler M. (1990). Phenotypic plasticity in the sailfin molly, Poecilia latipinna (Pisces: Poeciliidae). II. Laboratory Experiment. Evolution 44: 157-167.

Western Australian Local Government Association (2017). Submission to the Productivity Commission. Inquiry into Transitioning Regional Economies. Western Australian Local Government Association, Perth.
Wetland Research and Management (2009). 'Hope Downs 4 Aquatic Ecosystem Surveys: Dry Season Sampling 2008'. Unpublished report for Rio Tinto Iron Ore, Perth, Western Australia.

Wetland Research and Management (2015a). 'Iron Valley Project: Baseline Aquatic Fauna Survey: Weeli Wolli Creek. Wet Season 2015'. Unpublished report prepared for BC Iron Limited.

Wetland Research and Management (2015b). 'Iron Valley Project: Potential Impacts to Aquatic Systems: Literature Review'. Unpublished report prepared for BC Iron Limited.

Yamamoto M.N. and Tagawa A.W. (2000). Hawaii's Native and Exotic Freshwater Animals. Mutual Publishing, Honolulu.

MANUSCRIPT RECEIVED 15 NOVEMBER 2017; ACCEPTED 28 MAY 2018. 